\title{
Journal of Surgery
}

[Jurnalul de Chirurgie]

\section{The Beginnings of the First Surgical Unit of Cluj}

\section{Ionuț Isaia Jeican ${ }^{1,2 *}$, and Constantin Ciuce $^{3}$}

${ }^{1}$ Department of Anatomy and Embryology, "Iuliu Hațieganu" University of Medicine and Pharmacy, Cluj-Napoca, Romania

'Department of Head-Neck Surgery and Otorhinolaringology, University Clinical Hospital of Railway Company, "Iuliu Hatieganu" University of Medicine and Pharmacy, Cluj-Napoca, Romania

${ }^{3} 1^{\text {st }}$ Department of Surgery, "Iuliu Hațieganu" University of Medicine and Pharmacy, Cluj-Napoca, Romania

\begin{abstract}
The first Surgical Unit of Cluj was built between 1897-1899 as a unit of the newly founded "Carolina" National Hungarian University Hospital, which had been designed as a pavilion-type hospital. The surgical building rose on three levels and included the orthopedic outpatient unit, the surgical outpatient unit, a small operating unit, wards with 8 to 24 beds, laboratories, quarters for a part of the staff, teaching rooms, administrative rooms. The main space of the teaching activity was the lecture theater. The clinic capacity (100 beds) was exceeded immediately after its opening, which documents the importance of the Cluj medical center as early as the beginning of the $20^{\text {th }}$ century. The clinic had very well-defined functional routings, aimed at preserving the spaces in aseptic condition. This article depicts a piece of the medical history of Cluj, showing the place and the way our forerunner surgeons worked.
\end{abstract}

Keywords: Medical history; Surgery departments

\section{Introduction}

The "Ferencz József” Royal Hungarian University of Cluj was founded in 1872 and was the second university of the Hungarian Kingdom after the one in Budapest. At the end of the $19^{\text {th }}$ century the Carolina National Hospital of Cluj became associated with the Faculty of Medicine of the "Ferencz József" University, which led to the establishment of the first university hospital in Transylvania, with the first university clinics to be built in Cluj [1].

The site chosen for the clinics of this hospital was the south-west part of town, because there were few buildings and land was available here in those times [1].

The first project was drafted in 1885 by the renowned Hungarian architect Hauszmann Alajos and was considered unjustifiably grand and conceited by the leaders in Budapest, and also far from the liking of the professors of the Faculty of Medicine. Thus, after the finishing of the first two buildings of the complex (Institute of Anatomy and Institute of Physiology), in 1896 architects Korb Flóris and Giergl Kálmán were nominated to make a new project for the hospital [2]. Their project underwent a number of changes, the downsizing of the buildings being imposed by the continual budget constraints of the government [1].

\section{Completion of the building}

Korb Flóris and Giergl Kálmán made their project according to current conceptions of the time regarding hospital design, namely that the hospital sections had to be placed in separate pavilions, while administrative services (kitchen, laundry, disinfection etc.) were common and housed in other buildings. The concept of pavilion hospital originated in France in the $18^{\text {th }}$ century and was taken over and applied in England in the middle of the $19^{\text {th }}$ century. The main reason of this reform in hospital architecture lay in the role of ventilation in minimizing the patients' mortality rates, in accordance with the recent discoveries in microbiology [3-5].

In 1897 the construction of the Surgical Clinic began, at the same time with the buildings of Gynecology, Internal Medicine, Managerial and Housekeeping Pavilions, all of them finished and opened in the autumn of 1899. Land grading and soil stabilization, as well as underground drainage were difficult to achieve, given the sandy, sedimentary nature of the soil [2].
The clinic premises were designed as a park (Figure 1). The creation of such an atmosphere was also a result of the architects' and doctors' beliefs, which credited the hospital premises with an important role in patient recovery [6,7].

The clinic was built on three floors (basement, ground floor and upper floor), situated 7.5 meters from the street. The design followed the simple tract rule, namely a row of rooms on one corridor. This construction layout was not economical, but it ensured natural lighting and ventilation of all the spaces [1].

When it was inaugurated, the Surgical Clinic had 100 beds, over a build area of 1395 sq.m. However, discontent rose from the fact that

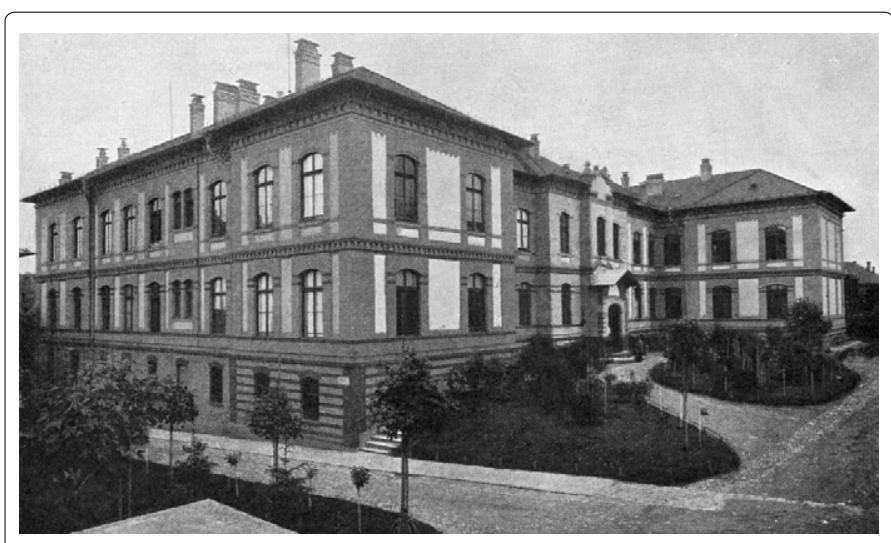

Figure 1: The clinic premises. A- South aspect (from A Kolozsvári M. K. Ferencz József Tudomány Egyetemek Emlékkönyve, Budapest: 1903; 291).

*Corresponding author: Ionuț Isaia Jeican, $1^{\text {st }}$ Department of Surgery, "Iuliu Hațieganu" University of Medicine and Pharmacy, Cluj-Napoca, Romania, Tel: +40 (0) 2645595 96; E-mail: ionutjeican@yahoo.com

Received September 04, 2018; Accepted October 04, 2018; Published October 11 2018

Citation: Jeican II, Ciuce C. The Beginnings of the First Surgical Unit of Cluj. Journal of Surgery [Jurnalul de chirurgie]. 2018; 14(4): 163-166 DOI: 10.7438/1584-9341-14-4-5

Copyright: ( 2018 Jeican II, et al. This is an open-access article distributed under the terms of the Creative Commons Attribution License, which permits unrestricted use, distribution, and reproduction in any medium, provided the original author and source are credited. 
the initial project had been down sized, as very soon after the Internal Medicine and Surgical Clinics struggled with the shortage of beds [2].

Even though the exterior aspects of the Internal Medicine and Surgical Clinics suggested a perfect symmetry, there were major differences at a functional level, imposed by the particular features of the specialties.

The building façade was an eclectic style, alternating plastered surfaces with brick-lined ones [1]. The main decorative elements of the façade are the outer framing of the amphitheater window and the frontispiece that bore the inscription of the official name of the institution: „SEBÉSZETI KLINIKA” (Surgical Clinic) [1]. The most remarkable inside decoration was the ironwork of the bannister of the main stairs [1], preserved to this day.

\section{Organization}

Given the structure of pavilion-type hospital, the clinic had certain autonomy in managing its activities, being led by a director-professor.

From a financial point of view, the state covered for $19 \%$ of the patients admitted to Carolina Hospital - the ones that presented an interest in teaching purposes. Medical services for the rest of the patients were provided by additional funds from the ministry or were paid by the patients [2].

In 1903, shortly after the opening, an album of the medical institutions of the "Ferencz József" University was published, containing a brief description of every clinic. The presentation of the Surgical Clinic was made by Dr. Brandt József, the director of the clinic at the time. This book made it possible for us to analyze the functional scheme of the clinic.

i. Basement: This level (Figure 2) housed: the orthopedic outpatient unit and the plaster cast room, administrative rooms (patients' dressing room, dirty laundry storeroom, heating system, water heaters, ventilation system, coal storage, maintenance workshop), and living quarters (for the nuns, ground man, building administrator and janitor) [8].

ii. Ground floor: The central hall housed the surgical outpatient unit, with two waiting rooms on both sides, one for women and one for men, where patients undressed and prepared for consultation [1]. The main hall also included the radiology laboratory and the entrance to the lecture theater for teachers and patients.

In the right wing of the ground floor were the professor's office, the library, the lodging of the intern and also a small operating block, composed of the operating room (9.3/5.4 m) (Figure 3), an anteroom - mounted on its wall was a device for water sterilization, a storage for surgical materials, and a sterilization room. There were two tables on which operations were usually performed. When the number of interventions exceeded the capacity of the operating block, operations also took place in the lecture theater, which could hold up to three tables [8].

The left wing housed three wards (one for children, with 16 beds (Figure 4), one for women with 8 beds and one for men with 10 beds), two single wards and two isolation wards for the first postoperative days (precursors of intensive care units) (Figure 5).

iii. Upper floor: The central part of the floor included the assistant physicians' quarters, the watch room, the clinic laboratory (bacteriology, biochemistry and histopathology) and the students' dressing room before the entrance to the lecture theater (Figure 6). The upper floor housed the largest patient wards of the Carolina hospital - two rectangular rooms with 24 beds, having a total surface of 180 sq.m, ensuring $7.5 \mathrm{sq} . \mathrm{m} / \mathrm{bed}$. The beds were arranged perpendicular on the long walls and the rooms had plenty light and air [1].
Over the upper floor there was a loft that was lit through the roof and a dark room for scientific photography. The attic contained the hot water tank, which supplied all the sinks and baths of the building [8].

iv. Lecture theater: This was the main space for the teaching activities, similar in design and architecture with other surgical lecture theaters in Europe and the United States at the end of the $19^{\text {th }}$ century [9] (Figure 7).

It has a capacity of 130 places. It was a separate building block, including two floor levels, joined to the main building frame. The students' access was from outside and the upper floor through two symmetrical spiral staircases. On the groundfloor the gradients were interrupted by three exits: two lateral and one central, for the teachers and "demonstration" patients. This way the patient flow was separated from the students' one [1].
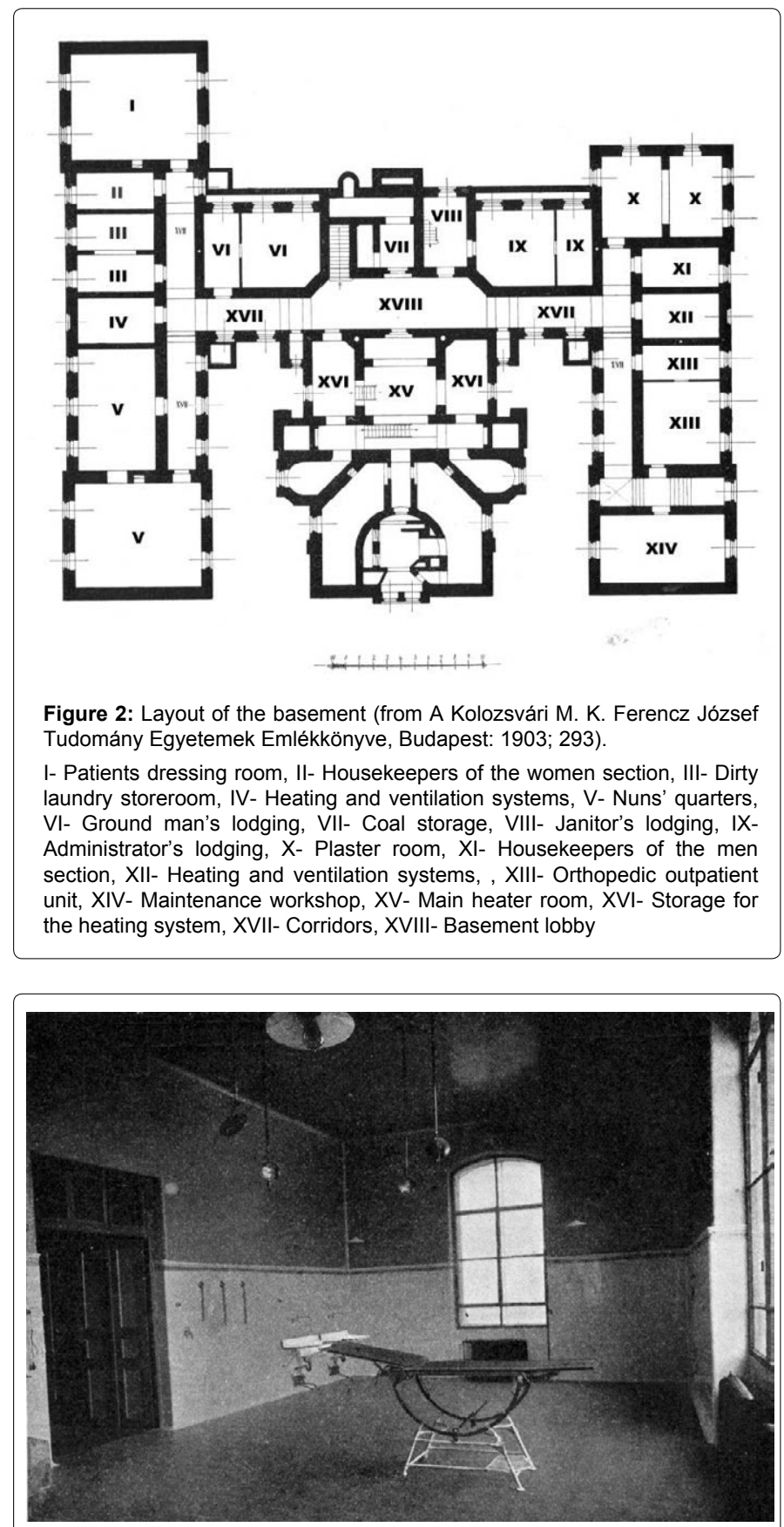

Figure 3: Operating room (from A Kolozsvári M. K. Ferencz József Tudomány Egyetemek Emlékkönyve, Budapest: 1903; 298). 


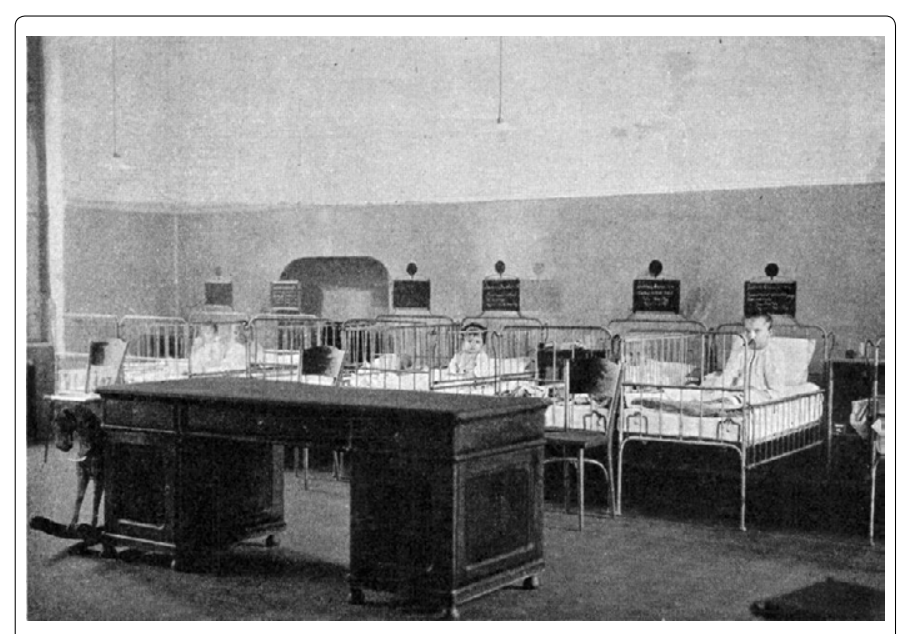

Figure 4: The children's ward of the clinic (from A Kolozsvári M. K. Ferencz József Tudomány Egyetemek Emlékkönyve, Budapest: 1903; 298).

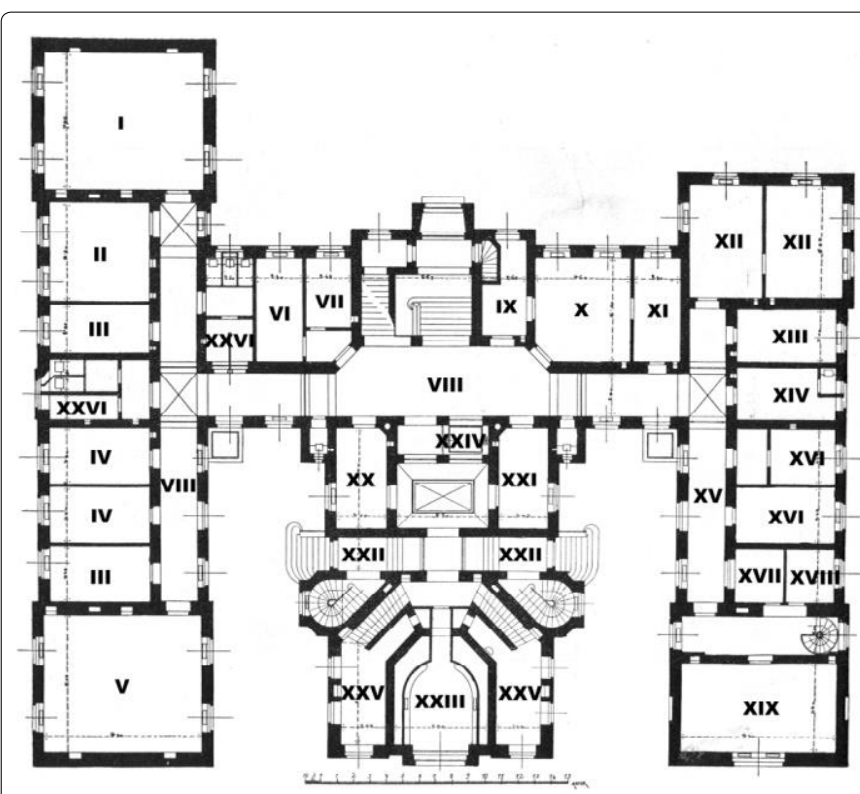

Figure 5: Layout of ground floor (from A Kolozsvári M. K. Ferencz József Tudomány Egyetemek Emlékkönyve, Budapest: 1903; 297).

I- Children's ward, II- Women's ward, III- Isolation ward, IV- Single ward, V- Men's ward, VI- Nurses' room, VII- Pantry, VIII- Lobby, IX, X, $\mathrm{XI}$ - Surgical outpatient rooms, XII- Professor's study room, XIII- Library, XIV- Doctors' bathroom, XV- Hallway, XVI- Intern's lodging, XVII- Surgical materials storeroom, XVIII Sterilization room, XIX- Aseptic operating room, XX- Projection room, XXI- Radiology laboratory, XXII- Entrance of lecture theater, XXIII- Lecture theater, XXIV- Elevator, XXV- Side exit, XXVI- Bathroom

This is the description of the lecture theater by the head of the clinic: "The lecture theater has natural light from above and the north; the walls are painted with an impermeable coating, while the floors are covered by porcelain tiles. Chairs are placed round the operating table, a metal frame with wooden boards [...]

Under the seats there is a large and high space like a corridor [side exit], used for the preparation of the patients for the operation, change of dressings etc. This space also includes two sinks with taps for cold and hot water [...] and 4 points of sterile water wash, foot-controlled flow [...] The water sterilization system [...] is based on gas burn [...]. The operating area also includes supports for irrigation [...], sterile sheets, electrical switch for the galvo-cautery and the Bottini type scalpel [...], a big blackboard for drawing, which may be rotated and fixed" $[8,9]$.

\section{Conclusion}

The first surgical clinic in Cluj was built in two years and its capacity was exceeded immediately after its inauguration, which documents the importance of the Cluj medical center ever since the beginning of the $20^{\text {th }}$ century.

The reference documents we studied evidence that the activity of the clinic was very well organized, with well-defined patient, personnel and students' flows, and with separate and reduced circulation of visitors or outpatients. It appears that the most important aspect of the clinic management, after the medical one - diagnosis and treatment - was the preservation of aseptic conditions, in accordance with the recent microbiological discoveries of the time.

Along the years, the clinic interior design underwent many changes, meant to adapt the space to the medical requirements of the times. The building exterior did not suffer substantial alterations and the restoration preserved the initial style.

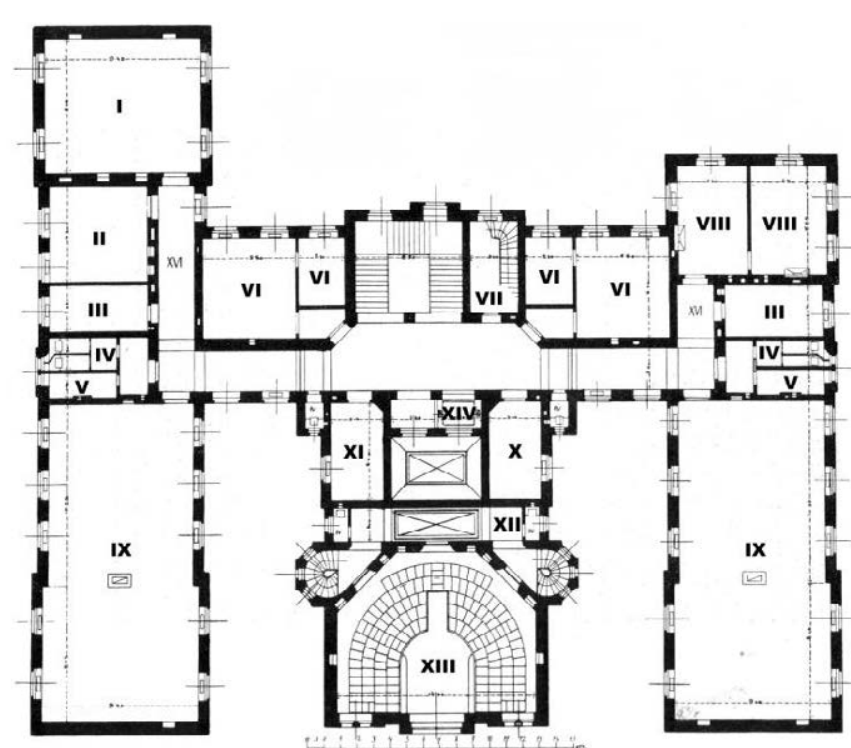

Figure 6: The upper floor layout (from A Kolozsvári M. K. Ferencz József Tudomány Egyetemek Emlékkönyve, Budapest: 1903; 299).

I- Men's ward (10 beds), II- Day ward, III- Pantry, IV- Toilet, V- Bathroom, VI- Assistant physicians' lodging, VII- Stairs to the loft and photo lab, VIIILaboratory, IX- Large patient wards (24 beds), X- Watch room, XI- Laundry storage, XII- Students' dressing room, XIII- Lecture theater, XIV- Elevator

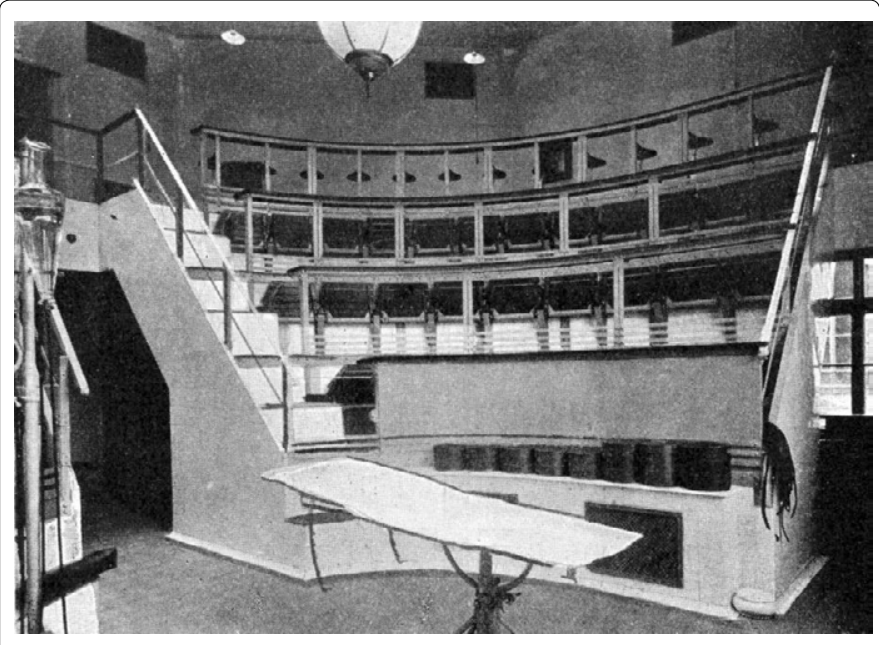

Figure 7: Lecture theater (from A Kolozsvári M. K. Ferencz József Tudomány Egyetemek Emlékkönyve, Budapest: 1903; 294). 
The clinics ensemble complex designed over a century ago are barely up to the challenges of the present time; however, reckless renovations and additions could deteriorate and even ridicule this architectural concept - a symbol of the medical history of Cluj.

\section{Conflict of Interest}

Authors have no conflict of interest to disclose.

\section{References}

1. Vais G (2007) Arhitectura clinicilor universitare din Cluj 1886-1903. Programe de arhitectură în Clujul perioadei 1867-1918. U.T. Press.

2. Szabó D (1903) A magyar kir. tud. egyetemi klinikák és Karolina országos kórház. A Kolozsvári M. K. Ferencz József Tudomány Egyetemek Emlékkönyve.

3. King A (1966) Hospital planning: revised thoughts on the origin of the pavilion principle in England. Med Hist 10: 360-373.
4. Cook GC (2002) Henry Currey FRIBA (1820-1900): leading Victorian hospital architect, and early exponent of the "pavilion principle". Postgrad Med J 78: 352-359.

5. Butler SV (2013) 'A model for the country': letters from Florence Nightingale to the architect, Thomas Worthington, on hospitals and other matters 1865-1868. Med Humanit 39: 91-97.

6. Permin H, Wagner $P$ (2009) Reasons for the construction of Bispebjerg Hospital - a hospital with light, air and freedom of nature. Dan Medicinhist Arbog 37: 21-50.

7. Lloyd S (1892) The Operating Pavilion of the New General Hospital at Hamburg. Ann Surg 16: 371-376.

8. Brandt J. Sebészeti Klinika (1903) A Kolozsvári M. K. Ferencz József Tudomány Egyetemek Emlékkönyve.

9. Adams A, Schlich T (2006) Design for Control: Surgery, Science, and Space at the Royal Victoria Hospital, Montreal, 1893-1956. Med Hist 50: 303-324. 